\title{
Empirical Evidence on the Impact of City Taxes
}

\author{
Charles Swenson ${ }^{1}$ \\ ${ }^{1}$ Professor and Leventhal Research Fellow, Marshall School of Business, University of Southern California Los Angeles, \\ CA 90089, USA \\ Correspondence: Charles Swenson, Professor and Leventhal Research Fellow, Marshall School of Business, University \\ of Southern California Los Angeles, CA 90089, USA.
}

\author{
Received: November 29, 2016 \\ Accepted: December 25, $2016 \quad$ Available online: December 27, 2016 \\ doi:10.11114/aef.v4i2.2111 \\ URL: http://dx.doi.org/10.11114/aef.v4i2.2111
}

\begin{abstract}
An important issue is whether cities can influence their own economic growths through municipal-level tax policy. There is little evidence on this to date, nor is there a clear a priori answer to this question. This study first documents municipal business tax rates across the United States, and finds they are a relatively significant cost to business. Next, using very a unique and precise government data set, the study examines the economic impacts of two previous tax cuts in Los Angeles and finds that these cuts generally resulted in growth in both the number of jobs and establishments.
\end{abstract}

Keywords: city taxes; tax policy; economic development

\section{Introduction}

An important issue is whether cities can influence their own economic growths through municipal-level tax policy. There is little evidence on this to date, nor is there a clear a priori answer to this question. On one hand, nearby municipalities are often very similar in terms of markets and infrastructure, so differences in tax structures might be important. Alternatively, such taxes are perceived as small relative to national taxes (and state taxes in the U.S.), and therefore unimportant at the margin to businesses. Overlaying this is a tension at the municipal government level; while job growth is important to cities, many cities face budget constraints which can be exacerbated by tax cuts.

The study first documents municipal tax rates across the United States and finds they are a relatively significant cost to business. Next, the study examines two previous tax cuts in Los Angeles using a unique database, and finds that such cuts generally had a positive economic impact, with elasticities roughly consistent with the limited prior research in this area. The findings are important insofar as they show that cities can in fact influence their economic growths through tax policy.

\section{Prior Research}

For the few studies of intra-regional effects of local taxes on cities (primarily U.S. cities), Bartik's (1992) literature review suggests that because non-tax factors tend to be similar between adjoining cities (i.e., they share local labor and other markets, as well as some infrastructure), differences in city tax structures should matter since they may be among the few distinguishing characteristics between such cities. The studies summarized in Bartik typically focused on property taxes, or on a select number of municipalities. Luce (1994) found that local taxes had a statistically significant influence on location of firms in the Philadelphia area. Mark et al (2000) found that sales and property taxes reduced employment growth in the District of Columbia area (DC, and nearby Virginia and Maryland communities). Wasmer and Anderson (2001) examined 112 Detroit area cities and found that some incentives affect the local value of commercial and manufacturing property, and Dye et al (2001) found that Chicagoland property taxes (and related classifications) had a negative influence on business activity. Wu (2010) examined 351 Massachusetts municipalities and found that property taxes had significant impact on business location and the related share of taxes borne.

Recent studies of European city taxes have found that city taxes can have an effect on industry location. Unlike their U.S. counterparts, these studies were at a national level. Rathelot and Silard (2008) found that city-level corporate income taxes decreased the number of plants in French cities over the 1994-2003 period. Duranton, Gobillon, and Overman (2011) found that while local property taxes did not decrease the number of new manufacturing plants in England, higher taxes did reduce employment.

This study extends the prior literature two ways, by: 
1. Documenting the aggregate amount of municipal business taxes across all U.S. cities and showing that such taxes are relatively substantial (implying that they may be salient); and

2. Isolating and calibrating the economic impacts of city tax changes in a very large city (Los Angeles) using prior tax changes with a unique government data set.

\section{How Significant Are Municipal Business Taxes?}

Cities impose a variety of taxes, licenses, and fees on business. Property taxes are generally set by state and county governments, but cities can often add a small per cent to tax bills. Similarly, sales/use taxes are set by states and counties, with cities adding a smaller amount. Although such taxes may be important, separating their incidence between businesses and individuals is challenging. The major city-imposed taxes on businesses tend to be either general business taxes, often in the form of an income tax or a gross receipts tax, or special business taxes, licenses, permits, and fees.

The structure of general business taxes varies widely by type, rate, and industry. To show this wide variation, consider these examples. Akron, Ohio, has a $2.5 \%$ tax on gross payroll plus a $2.5 \%$ income tax on firms that pay a state income tax; Baton Rouge, Louisiana has a .1\% tax on gross receipts (maximum tax of \$2000), except that retail has a separate tax structure (maximum tax of \$7500); Jacksonville, Florida has a \$5 per employee tax, but retailers and wholesalers have a separate tax structure. Tucson, Arizona has a $2 \%$ tax on gross receipts, but only for retail and wholesale - and rentals have a separate tax structure.

Other business taxes, licenses, and fees also vary widely. Other business taxes include taxes on public utility gross receipts, occupancy taxes for hotel guests, and parking taxes. Business licenses and fees can include general and specific activity licenses, construction fees and permits, development impact fees, environmental impact fees, scheduled traffic impact fees, signalization fees, art in public places fees, major thoroughfare/bridge fees, and utility user fees and taxes. The sheer variation in such business taxes makes any sort of marginal rate calculation seemingly impossible. Accordingly, deriving an average effective rate seems more sensible.

To establish some perspective on whether municipal business taxes are potentially important to businesses, it is necessary first to examine their overall economic significance. To do this, tax revenues at a detailed level, by city, were collected from the Census of Local Governments (Bureau of the Census, various years) for 1998 through 2007. From this data, taxes, fees, and licenses imposed on business were isolated. Since larger cities will typically have larger tax collections, it is necessary to scale such collections to gauge their relative importance. We can scale business taxes as a per cent of total city tax collections, and we can also develop an overall, average effective business tax rate. To develop this latter statistic, we divide municipal business tax collections ${ }^{1}$ for each state by state "business income" for that year. Business income is proprietors' incomes for that state and year reported by the Bureau of Economic Analysis (BEA).

Table 1 reports such taxes by state for 2003-7. As can be seen, the average rates of $8.835 \%$ as a per cent of total city taxes and $3.947 \%$ as a per cent of business incomes are relatively significant. We can also see a wide variation by state, from a low of .5\% in South Dakota to a high of $11 \%$ in New York. It is important to note that this business tax measure excludes two potentially significant taxes--property and sales, which given the aggregate nature of data reported, we cannot reliable apportion to the business sector versus the individual sector ${ }^{2}$. Table 2 shows that such rates were relatively stable from 1998-2006, in terms of percents of total city tax collections. Table 2 also shows that city business taxes are apparently not a function of city size; there is a negative, but statistically insignificant, correlation with city population and business tax rates.

\footnotetext{
${ }^{1}$ Business taxes are (using the Census categories): Amusement License, Corporation License, Public Utility License, Occupancy and Business Licenses NEC, Corporate Net Income Tax, Severance Tax, Alcoholic Beverage License, Other License Taxes, and Taxes NEC (which on investigation of city financials turned out to be business taxes). Although businesses also pay property and sales taxes, the aggregate data reported by Census does not break these taxes out into those paid by businesses versus individuals. Note that because the publicly-available Census dataset is aggregated at the state level, detailed data for all sub-state governments was requested and received under the Freedom of Information Act (FOI).

${ }^{2}$ The magnitudes of property and sales tax collections are significant, averaging 46.7 per cent and 24.2 per cent, respectively, of city tax collections.
} 
Table 1. Effective Overall City Business Tax Rates, Averaged by State, 2003-2007 Average

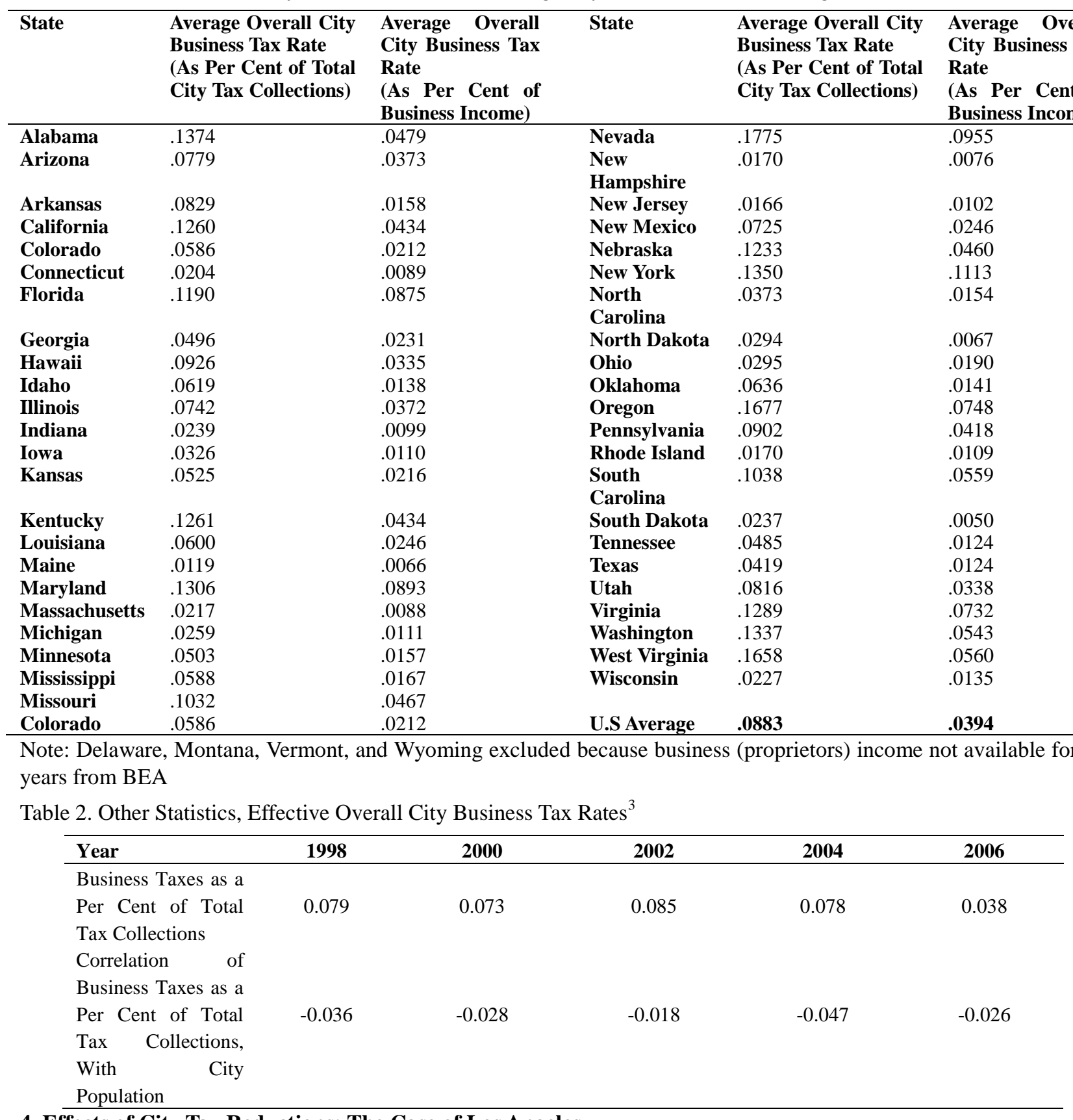

\section{Effects of City Tax Reductions: The Case of Los Angeles}

The author was engaged as the principal investigator (PI) by the City of Los Angeles to examine various proposals for reform of the City's general business tax. As part of this analysis, two actual tax changes in the past were examined in an attempt to estimate the responsiveness of the Los Angles business community to a particular tax. This exercise was afforded by a unique, confidential dataset provided by the City and derived from actual tax records. As such, it offers a unique opportunity to estimate the economic impact of municipal taxes in a city tax setting.

While this case study can only be considered suggestive, it does inform the general municipal business tax discussion given the limited amount of evidence on the topic. Moreover, the elasticities found here are similar to those summarized by Bartik (1992) in his survey of the impact of other types of taxes on other cities.

The City of Los Angeles gross receipts tax historically has accounted for $10 \%$ of City revenues, which amounted to $\$ 424$ million in revenue in FY2010-2011. Most for-profit industries are taxed, with rates ranging as high as

${ }^{3}$ For approximately 7800 cities reporting. Some cities are missing some data. 
\$ 5.07/thousand of gross receipts (sales ${ }^{4}$ ), depending on industry. Exceptions to taxation exist for certain small businesses. A major concern of the City was that its tax structure was not competitive vis-à-vis other nearby cities. Accordingly, as part of the project California cities' tax structure data were gathered and compared. Table 3 shows results of this tabulation for Los Angeles County cities which are in very close proximity to Los Angeles, i.e., they are competitors for businesses. There is no consolidated data source for such data so web sites and other city documents were used to gather this data. As can be seen, the City's conjecture was correct; with the exceptions of Beverly Hills and Culver City, Los Angeles business tax rates were easily the highest in LA County.

Table 3. Business Tax Rates for Select California Cities (2007 Rate per \$1000 of Gross Receipts)

\begin{tabular}{|c|c|c|c|}
\hline CITY & HIGHEST RATE & MEDIAN RATE & LOWEST RATE \\
\hline Alhambra & .19 & .19 & .19 \\
\hline Arcadia & Employee based & Employee based & Employee based \\
\hline Azusa & $.96^{1}$ & $.16^{1}$ & .16 \\
\hline Baldwin Park & Employee based & Employee based & Employee based \\
\hline Bell & .44 & .44 & .44 \\
\hline Bell Gardens & Employee based & Employee based & Employee based \\
\hline Bellflower & Employee based & Employee based & Employee based \\
\hline Beverly Hills & $\begin{array}{l}\text { Mixture of gross receipts and } \\
\text { Employee based; } \\
\text { for certain industries subject to gross } \\
\text { receipts taxes, highest rate is } \$ 23.89 \\
\text { (commercial property rental only) }\end{array}$ & $\begin{array}{l}\text { Mixture of gross receipts and } \\
\text { Employee based; } \\
\text { for certain industries subject to } \\
\text { gross receipts taxes, median rate is } \\
\$ 1.27\end{array}$ & $\begin{array}{l}\text { Mixture of gross receipts and } \\
\text { Employee based; } \\
\text { for certain industries subject to } \\
\text { gross receipts taxes, lowest rate is } \\
\$ 1.27\end{array}$ \\
\hline Burbank & Employee based & Employee based & Employee based \\
\hline Calabasas & 0 & 0 & 0 \\
\hline Claremont & 1.10 & .31 & .04 \\
\hline Compton & 1.07 & .29 & .29 \\
\hline Culver City & 3.01 & 1.01 & 1.01 \\
\hline Diamond Bar & 0 & 0 & 0 \\
\hline El Monte & 1.47 & .21 & .21 \\
\hline Gardena & 1.01 & .55 & .51 \\
\hline Glendale & 0 & 0 & 0 \\
\hline Hawthorne & 1.00 & 1.00 & 1.00 \\
\hline Huntington & .4 & .4 & .4 \\
\hline \multicolumn{4}{|l|}{ Park } \\
\hline Inglewood & 1.65 & 1.10 & 1.10 \\
\hline Irwindale & .33 & .33 & .33 \\
\hline La Puente & Employee based & Employee based & Employee based \\
\hline La Verne & .21 & .21 & 0 \\
\hline Lawndale & Employee based & Employee based & Employee based \\
\hline Lomita & $.85^{1}$ & $.85^{1}$ & .85 \\
\hline Long Beach & Employee based & Employee based & Employee based \\
\hline Los Angeles & 5.07 & $2.55 / 1.27$ & 1.01 \\
\hline Manhattan & 1.79 & 1.79 & 1.79 \\
\hline \multicolumn{4}{|l|}{ Beach } \\
\hline Monterey Park & Employee based & Employee based & Employee based \\
\hline Palmdale & .56 & .13 & .06 \\
\hline Pasadena & $\begin{array}{l}\text { Either no tax or employee based tax, } \\
\text { depending on industry }\end{array}$ & $\begin{array}{l}\text { Either no tax or employee based } \\
\text { tax, depending on industry }\end{array}$ & $\begin{array}{l}\text { Either no tax or employee based } \\
\text { tax, depending on industry }\end{array}$ \\
\hline Pico Rivera & .31 & .31 & .31 \\
\hline Pomona & 1.16 & .96 & .08 \\
\hline San Fernando & 1.47 & .21 & .21 \\
\hline San Gabriel & Employee based & Employee based & Employee based \\
\hline Santa Monica & 5.03 & 1.28 & 1.28 \\
\hline Temple City & Employee based & Employee based & Employee based \\
\hline Torrance & Employee based & Employee based & Employee based \\
\hline West & .01 & 0 & 0 \\
\hline
\end{tabular}

Hollywood

Los Angeles enacted two relatively significant tax holidays in the last decade that we can examine. Effective January 1, 2001, a "new business" holiday was enacted for all firms with gross receipts of less than $\$ 500,000$. The holiday applied only in the first two years of operations. In July 2006 (effective January 1, 2007) the small business tax exemption was doubled to $\$ 100,000$ of annual gross receipts. If these tax holidays were effective, we would expect to see increases

\footnotetext{
${ }^{4}$ Throughout this report the term "sales" is sometimes used, and "gross receipts" is also sometimes used. Both relate to the revenues which a company generates.
} 
both in the number of LA firms and in related employment statistics ${ }^{5}$.

To test the effectiveness of these law changes, two databases were used: the LATAX data from the City of Los Angeles, and the 2009 D\&B/National Establishment Time-Series (NETS) Database, both of which allow identification of establishments within precise city borders ${ }^{6}$. Such exact locational data is important since city taxes generally can only be assessed on businesses physically located within the city's borders. The LATAX database contains firm-specific data on all taxes paid to the City from 2001 to 2010 including firm specific information ${ }^{7}$ such as name, address, and taxable gross receipts. ${ }^{8}$ The 2009 NETS database is a unique, firm-specific database derived from the Dun \& Bradstreet data, and contains an annual time-series of information on over 36.5 million U.S. establishments from January 1990 to January 2010. Unlike other program-readable annual firm databases (such as Standard and Poor's Compustat), NETS reports exact geographic locations of the firms/establishments and of their subsidiaries, as well as other variables such as sales, employment, and SIC $^{9}$. Also, the database shows dates a business was located at a particular address so we can determine when an establishment moved to a city or if it was born there. ${ }^{10}$

Significant differences distinguish the two databases. LATAX has information on firms that pay business taxes to LA, whereas NETS is based in part on voluntary participation by firms to a mailed Dun \& Bradstreet survey and, accordingly, participation is smaller for very small firms with sales under $\$ 100,000$. Both LATAX and NETS have exact location, name, revenue, and SIC/NAICS code data, by establishment, but only NETS has employment data. The differences allow for "triangulation" in the sense that we can use both to estimate potential economic impacts of LA business tax changes. Also, LATAX data includes establishments which pay taxes to Los Angeles but are outside of the City limits. In contrast, NETS data allows precise identification of only establishments within the City of Los Angeles borders, potentially allowing a more precise impact analysis of LA tax policies on only LA-based firms. Because LATAX includes some firms outside of LA, and also requires the filing of separate returns when a firms has separate lines of business (thus has separate tax rates), this dataset has more observations than does the D\&B/NETS database.

To examine the impact of the 2001 and 2007 law changes, we can look at the economic impact immediately before and after the law change, using both LATAX and NETS data. In examining whether tax law/rule changes have an economic impact, we of course want to control for trends and potentially unobserved variables that could affect business activity. In the absence of any existing empirical models, we can attempt to control for such trending and other effects with a differences-in-differences (DID) specification. Since the work by Ashenfelter and Card (1985), the use of difference-in-differences methods has become very widespread in policy analysis. ${ }^{11}$ The simplest case is one where outcomes are observed for two groups for two time periods. One of the groups is exposed to a treatment in the second period but not in the first period, and the second group is not exposed to the treatment during either period. If the same units within a group are observed in each time period, the average gain in the second (control) group is subtracted from the average gain in the first (treatment) group. This removes biases in second period comparisons between the treatment and control group that could be the result from permanent differences between those groups. It also removes biases from comparisons over time in the treatment group that could be the result of trends. Using a regression of the form $\mathrm{y}=$ $\beta_{0}+\beta_{1} \mathrm{~dB}+\delta_{0} \mathrm{~d} 2+\delta_{1} \mathrm{~d} 2 * \mathrm{~dB}+\mathrm{e}$, the regression estimate of $\mathrm{d} 2$ is a dummy variable for the second time period. The

${ }^{5}$ It is important to note that LA also enacted a number of other tax reforms which are more problematic to test. For example, tax reductions to certain industries (e.g., motion pictures) may or may not be generalizable to all LA firms. Also, gradual 15\% reductions in tax rates starting in 2006 are relatively small and more importantly, because they occurred in succession, analyzing the effects of rates of change from one year to the next is more difficult to isolate.

${ }^{6}$ Government sources from Census (such as Census of Business and County Business Patterns) and BEA at best report many data items at the county level or Metropolitan Statistical Area (MSA) level, the latter of which tends to be an agglomeration of adjoining incorporated cities. Also, the level of detail is far less than that reported in D\&B/NETS

${ }^{7}$ To preserve confidentiality the database provided by the City did not include Social Security numbers or Federal Employment Identification (FEIN) numbers.

${ }^{8}$ This data was provided to the author by the City of Los Angeles on a confidential basis.

${ }^{9}$ Note that government publications such as County Business Patterns frequently aggregate data at the MSA level and cannot necessarily determine the number of firs located within exact city borders.

${ }^{10}$ Because participation in the D\&B survey is voluntary, there is of course potential for response bias. A number of academic studies have used this database. See N. Wallace, "Agglomeration Economies and the HiTech Computer Sector": http://repositories.cdlib.org/iber/fcreue/fcwp/292 and "The Role of Job Creation and Job Destruction Dynamics" in Glaeser \& Quigley, Housing Markets and the Economy (2009). Also see Kolko and Neumark (2010) "Do Enterprise Zone Create Jobs? Evidence from California's Program" Journal of Urban Economics.

${ }^{11}$ See Ham et al (2011) for an example in the state tax policy context. 
dummy variable $\mathrm{dB}$ captures possible differences between the treatment and control groups prior to the policy change. The time period dummy, $\mathrm{d} 2$, captures aggregate factors that would cause changes in y even in the absence of a policy change. The DID coefficient, $\delta_{1}$, multiplies the interaction term, $\mathrm{d} 2 * \mathrm{~dB}$, which is the same as a dummy variable equal to one for those observations in the treatment group in the second period.

As shown in Woolridge (2007), the DID method for a panel of data involves time and group dummy variables, with the DID variable being a dummy variable set to 1 for the treatment group during the treatment periods. Accordingly, we specify:

$$
Y_{i t}=\alpha_{i}+v_{t}+\delta_{1} T X_{i t}+\varepsilon_{i t}
$$

where and $\mathrm{Y}_{\mathrm{it}}$ is employment for establishment $i$ in year $t, \quad \alpha_{i}$ are year dummies, $v_{t}$ is a dummy variables set to 1 if the establishment was part of the treatment group (subject to tax change), and $T X$ is the interaction of the $T X$ variable and the year in which the tax change was put into effect (i.e., this is the treatment variable of interest). As noted in Woolridge (2007), (1) can be estimated using a fixed effects OLS model.

\subsection{Law Change in 2001}

Before examining econometric (DID) results, it is instructive to examine aggregate changes. Using the NETS database, data for firms affected by the "under $\$ 500 \mathrm{k}$ in sales" tax holiday policy is shown in Panel A of Table 4.To evaluate the employment growth for LA based firms subject to the new business exemption, we can compare such firms' growth to control groups. To control for trends we can compare changes in changes to the affected LA firms versus changes in changes to the control group. One such group would be LA firms with sales in excess of $\$ 500,000$. Data for this group of larger LA-based firms is shown in Panel B of Table 4.

Table 4: Effects of 2001 Los Angeles Business Tax Changes-Aggregate Comparisons

Panel A: D\&B Data ${ }^{12}$ : Los Angeles Companies With Sales $<\$ 500,000$

\begin{tabular}{ccccc}
\hline Year & Total Employment & \% Change Over Prior Year & Number of Establishments & \% Change Over Prior Year \\
\hline $\mathbf{1 9 9 9}$ & 243,882 & & 86,560 & $7.48 \%$ \\
$\mathbf{2 0 0 0}$ & 260,220 & $6.70 \%$ & 93,037 & $8.76 \%$ \\
$\mathbf{2 0 0 1}$ & 284,605 & $9.37 \%$ & 101,187 & $21.94 \%$ \\
$\mathbf{2 0 0 2}$ & 341,025 & $19.82 \%$ & 123,387 & \\
\hline
\end{tabular}

Panel B: D\&B Data: Los Angeles Companies With Sales $>\$ 500,000$

\begin{tabular}{lcccc}
\hline Year & Total Employment & \% Change Over Prior Year & Number of Establishments & \% Change Over Prior Year \\
\hline $\mathbf{1 9 9 9}$ & $1,066,773$ & & 36,667 & \\
$\mathbf{2 0 0 0}$ & $1,151,759$ & $7.97 \%$ & 39,191 & $6.88 \%$ \\
$\mathbf{2 0 0 1}$ & $1,174,548$ & $2.00 \%$ & 40,308 & $2.85 \%$ \\
$\mathbf{2 0 0 2}$ & $1,189,401$ & $1.26 \%$ & 40,783 & $1.18 \%$ \\
\hline
\end{tabular}

Panel C: D\&B Data: All Other California Companies (in MSAs) With Sales > \$500,000

\begin{tabular}{lcccc}
\hline Year & Total Employment & \% Change Over Prior Year & Number of Establishments & \% Change Over Prior Year \\
$\mathbf{1 9 9 9}$ & $5,639,995$ & & 191,606 & \\
$\mathbf{2 0 0 0}$ & $6,117,615$ & $8.47 \%$ & 206,645 & $7.85 \%$ \\
$\mathbf{2 0 0 1}$ & $6,336,846$ & $3.58 \%$ & 211,614 & $2.41 \%$ \\
$\mathbf{2 0 0 2}$ & $6,434,782$ & $1.55 \%$ & 215,287 & $1.74 \%$ \\
\hline
\end{tabular}

Panel D: D\&B Data: NEW Los Angeles Companies With Sales $<\$ 500,000$

\begin{tabular}{ccc}
\hline Year & Total Employment of New Firms in First Year of Operations & \% Change Over Prior Year \\
1999 & 71,566 & \\
2000 & 99,999 & $39.73 \%$ \\
2001 & 161,341 & $61.34 \%$ \\
\hline
\end{tabular}

Panel E: D\&B Data: All Other NEW California Companies (in MSAs) With Sales $<\$ 500,000$

\begin{tabular}{ccc}
\hline Year & Total Employment of New Firms in First Year of Operations & \% Change Over Prior Year \\
\hline 1999 & 421,387 & \\
2000 & 574,562 & $36.35 \%$ \\
2001 & 738,294 & $28.50 \%$ \\
\hline
\end{tabular}

\footnotetext{
${ }^{12}$ Note that a number of observations were lost because of restricting the sample to only those companies which reported sales data. These firms may have had some reported sales outside of Los Angeles. In that case, their Los Angeles sales are clearly under $\$ 500 \mathrm{k}$, qualifying them for the exemption.
} 
Panel F: LATAX Data: Companies With Taxable Gross Receipts $<\$ 500,000$

\begin{tabular}{|c|c|c|c|c|c|c|c|c|}
\hline Year & Gross Receipts & $\begin{array}{c}\text { \% Change Over } \\
\text { Prior Year }\end{array}$ & Tax Paid & \multicolumn{2}{|c|}{$\begin{array}{c}\% \text { Change Over } \\
\text { Prior Year }\end{array}$} & \multicolumn{2}{|c|}{$\begin{array}{c}\text { Number of } \\
\text { Companies Filing }\end{array}$} & $\begin{array}{r}\% \text { Chat } \\
\text { Priol }\end{array}$ \\
\hline 1999 & $\$ 14,645,651,945$ & & $\$ 52,762,075$ & \multirow{2}{*}{\multicolumn{2}{|c|}{$648 \%$}} & 186,460 & & \\
\hline 2000 & $\$ 14,920,217,971$ & $1.88 \%$ & $\$ 56,183,325$ & & $8 \%$ & 186,423 & & $-.01 \%$ \\
\hline 2001 & $\$ 15,120,390,211$ & $1.34 \%$ & $\$ 51,096,932$ & \multicolumn{2}{|c|}{$-9.51 \%$} & 193,262 & & $3.67 \%$ \\
\hline 2002 & $\$ 15,880,253,292$ & $5.00 \%$ & $\$ 50,970,753$ & \multicolumn{2}{|c|}{$-.21 \%$} & 209,155 & & $8.29 \%$ \\
\hline \multicolumn{9}{|c|}{ Panel G: LATAX Data: Companies With Taxable Gross Receipts > \$500,000 } \\
\hline Year & Gross Receipts & $\begin{array}{c}\text { \% Change } \\
\text { Over Prior } \\
\text { Year }\end{array}$ & \multicolumn{2}{|l|}{ Tax Paid } & $\begin{array}{c}\text { \% Change } \\
\text { Over Prior } \\
\text { Year }\end{array}$ & $\begin{array}{c}\text { Number of } \\
\text { Companies } \\
\text { Filing } \\
\end{array}$ & \multicolumn{2}{|c|}{$\begin{array}{c}\text { \% Change } \\
\text { Over Prior } \\
\text { Year }\end{array}$} \\
\hline \multirow{2}{*}{$\begin{array}{l}1999 \\
2000\end{array}$} & $\$ 91,604,856,248$ & \multirow[b]{2}{*}{$6.55 \%$} & $\$ 221,484,2$ & \multirow{2}{*}{\multicolumn{2}{|c|}{$8.15 \%$}} & 28,010 & \multirow{2}{*}{\multicolumn{2}{|c|}{$4.00 \%$}} \\
\hline & $\$ 97,214,141,384$ & & \multirow{3}{*}{\multicolumn{2}{|c|}{$\begin{array}{c}\$ 238,987,899 \\
\$ 260,039,868 \\
\$ 264,369,986\end{array}$}} & & 29,124 & & \\
\hline 2001 & $\$ 105,432,421,924$ & $8.25 \%$ & & & $8.79 \%$ & 30,378 & 4.319 & \\
\hline 2002 & $\$ 110,697,912,667$ & $5.71 \%$ & & & $1.54 \%$ & 31,516 & $3.75 \%$ & \\
\hline
\end{tabular}

Table 4 shows that prior to the exemption (from 1999-2000), LA firms with sales under $\$ 500 \mathrm{k}$ experienced a $6.7 \%$ employment growth. After the exemption, they experienced a 9.37\% employment growth. Thus, the change, after controlling for the previous year's trend, was a $2.67 \%$ job increase. Prior to the exemption (from 1999-2000), LA firms with sales over $\$ 500 \mathrm{k}$ experienced a $7.97 \%$ employment growth. After the exemption, they experienced a $2.0 \%$ employment growth. Thus, the change, after controlling for the previous year's trend, was a $5.97 \%$ job decrease. Comparing the two groups of LA firms, the firms with sales under \$500k experienced an $8.64 \%$ job increase (or $2.67 \%$ minus $-5.97 \%)$. This difference in differences is significant at .001 using a $Z$ test of differences in population proportions.

If, instead of employment, we use number of establishments, we find the following. Table 4 shows that prior to the exemption (from 1999-2000), LA firms with sales under \$500k experienced a $7.48 \%$ growth in the number of establishments. After the exemption, this group experienced an $8.76 \%$ growth in firms. Thus, the change, after controlling for the previous year's trend, was a 1.28\% increase. Prior to the exemption (from 1999-2000), LA firms with sales over $\$ 500 \mathrm{k}$ experienced a $6.88 \%$ growth in the number of establishments. After the exemption, they experienced a $2.85 \%$ growth in the number of establishments. Thus, the change, after controlling for the previous year's trend, was a $4.03 \%$ decrease. Thus, comparing the two groups of LA firms, the firms with sales under $\$ 500 \mathrm{k}$ experienced a $5.31 \%$ increase (or $1.28 \%$ minus $-4.03 \%$ ). This difference in differences is significant at .001 (using a $Z$ test of differences in population proportions).

If we use instead other California firms, not based in LA, but based in other Metropolitan Statistical Areas (MSAs) and with sales of under $\$ 500 \mathrm{k}$, we see the following results. As shown in Panel C of Table 4, these firms experienced $7.71 \%$ and $7.31 \%$ growth in employment from 1999-2000 and 2000-2001, respectively. Thus there was a .4\% decline, after controlling for trend, after 2000. Comparing them to the LA-based firms with sales of under $\$ 500 \mathrm{k}$ (the treatment group), we see the latter experienced a relative growth of $3.07 \%$ after the exemption, and this difference in differences is significant at .001 (using a $Z$ test of differences in population proportions).

Averaging the above two comparisons, the new exemption was associated with a 5.86\% direct job growth in firms with sales of under $\$ 500 \mathrm{k}$. A major strength of examining the change in all firms with sales under $\$ 500,000$, as opposed to examining only new firms with sales under $\$ 500,000$ which started business after the tax holiday, is that we control for potential crowding out effects. That is, if the net number of firms increased, any effects of crowding out must be small. However, we can re-analyze the data examining only new firms (with sales under $\$ 500,000$ ) starting in Los Angeles before and after the law change. Panel D shows that for new LA firms, the relative change in employment growth was $21.6 \%$ after the exemption, or $61.34 \%-39.73 \%$. Panel E shows that for new non LA firms, the relative change in employment growth in 2001 was a decline of $7.85 \%$, or $28.5 \%-36.35 \%$. Comparing LA firms to non-LA firms, we see that LA-based firms' change in 2001 employment growth was thus $29.46 \%$ higher. These results show a much more dramatic effect of the 2001 tax holiday than shown in the preceding panels, but again, the reader is cautioned that these do not measure whether some crowding out of existing firms may also have occurred. It is worth noting that we cannot compare 2001 employment growth for LA firms with sales over $\$ 500,000$, since according to the NETS data, there were no new establishments created by these firms in 2001.

Although LATAX data does not have employment data, we can use it to examine growth in the number of firms affected 
by the new policy. Panels $\mathrm{F}$ and $\mathrm{G}$ of Table $4^{13}$ show data for firms affected by the policy, as well as data for larger LA firms. To control for trends we compare changes to the affected LA firms versus changes in changes to the control group. ${ }^{14}$ The number of firms in under 500k sales category grew, after controlling for pre law change trend, by $3.68 \%$. In contrast, controlling for pre-tax law change trend, firms with gross receipts over 500k grew by.31\%. Thus, the difference in differences between the two groups is a 3.35\% higher growth rate in the under 500k firms, which is significant at .001 (using a $Z$ test of differences in population proportions).

In summary (and using aggregate data), the 2001 new business exemption appears to have created economic growth, although the two databases provide slightly different pictures. The NETS database indicates average employment and number of establishment growths of 5.86\% and $4.135 \%$, respectively, for firms affected by tax cuts. The LATX data shows a 3.35\% growth in the number of firms in the tax cut category. Elasticities are as follows. First, if we assume a 10-year investment horizon, then (ignoring the time value of money) a one-year tax exemption is equivalent to a $10 \%$ tax decrease (note that the law change allowed a two-year exemption, but because we are examining a single year only, this is equivalent to a $10 \%$ change). For employment, since employment increased $5.86 \%$, we get a labor elasticity (with respect to each percent change in tax) of -.586. For number of establishments, if we simply average results for NETS and LATAX, growth is $2.07 \%$, which implies an elasticity of -.207.

Econometric (DID regression) results are shown in Table 5. Model (1) uses employment from D\&B data, and the comparison group is Los Angeles establishments with gross receipts $>\$ 500 \mathrm{k}$. Model (2) uses employment from D\&B data, and the comparison group is all other California establishments with gross receipts $<\$ 500 \mathrm{k}$. Model (1) estimates that the law change increased employment by $10.8 \%$ for the tax cut establishments. Model (2) estimates much more modest results, with employment increases of $1.54 \%$. The results are statistically significant at .001 for both models. The average of these two estimates is $6.17 \%$, which is quite similar to the $5.86 \%$ estimate using aggregate data, reported in the previous paragraph.

Table 5. Effects of 2001 Los Angeles Business Tax Changes-Difference in Differences (DID) Econometric Analysis

\begin{tabular}{lcc}
\hline & Growth in Employment (1) & Growth in Employment (2) \\
\hline Constant & $-.12326^{* * *}(.01009)$ & $.07585^{* * *}(.00209)$ \\
Tax & $.10824 * * *(.01010)$ & $.01548 * * *(.00396)$ \\
$\begin{array}{l}\text { Establishment } \\
\text { dummies }\end{array}$ & Yes & Yes \\
Year dummies & Yes & Yes \\
$\begin{array}{l}\text { Number of } \\
\text { establishments }\end{array}$ & 471,115 & $1,617,727$ \\
Model $\quad F$ & $1067.30^{* * *}$ & $5.24 * * *$ \\
Statistic & & \\
\hline
\end{tabular}

$* / * * / * * *$ denote significance at the $5 \%, 1 \%$, and $0.1 \%$ levels, respectively. Robust standard errors in parentheses. Time period is 1999 through 2002. Model (1) uses D\&B data, and the comparison group is Los Angeles establishments with gross receipts $>\$ 500 \mathrm{k}$. Model (2) uses D\&B data, and the comparison group is all other California establishments with gross receipts $<\$ 500 \mathrm{k}$.

\subsection{Law Change in 2007}

Effective January 1, 2007, the small business exemption was doubled to companies having global sales under $\$ 100,000^{15}$. It is important to recall that 2007 was the start of the Great Recession so we would expect to see economic decline in number of firms, sales, and employment figures in general. To evaluate the employment growth for LA based firms subject to the small business exemption, we compared such firms' growth to control groups. To control for trends we compared changes in changes to the affected LA firms versus changes in changes to the control group. As with the 2007 law change, it is instructive to not only perform econometric estimates, but aggregate analyses as well.

\footnotetext{
${ }^{13}$ It is important to note that starting in 2001, the Los Angeles Office of Finance (which administers the tax) increased compliance (partly as a result of AB 63) through discovery measures. The Table only includes firms which were not part of the discovery process.

${ }^{14}$ The Table also shows gross receipts and taxes paid for each group. These are for information only, since both are expected to drop for the smaller firms due to the tax break (which is what we observe).

${ }^{15}$ It applies to companies having global sales of under $\$ 100 \mathrm{k}$.
} 
Panel A of Table 6 shows aggregate NETS-based data for firms affected by the new policy, i.e, those having sales below $\$ 100,000$. One control group would be other LA firms with sales in excess of $\$ 100,000$; these firms are shown in Panel B of Table 6. Prior to the exemption (from 2005-2006), LA firms with sales under $\$ 100 \mathrm{k}$ experienced an $11.61 \%$ employment growth. After the exemption, they experienced an $8.0 \%$ employment growth. Thus, the change, after controlling for the previous year's trend, was a 3.61\% job decrease. Prior to the exemption (from 2005-2006), LA firms with sales over $\$ 100 \mathrm{k}$ experienced a $-.26 \%$ employment decline. After the exemption, they experienced a $2.07 \%$ employment growth. So the change, after controlling for the previous year's trend, was a $2.33 \%$ job increase. Thus, comparing the two groups of LA firms, the firms with sales under \$100k (i.e., those in the tax cut group) experienced a $5.94 \%$ job decrease (or $3.61 \%$ plus $2.33 \%$ ).

Table 6: Effects of 2007 Los Angeles Business Tax Changes-Aggregate Comparisons

Panel A: D\&B Data ${ }^{16}$ : Los Angeles Companies With Sales Under \$100,000

\begin{tabular}{ccccc}
\hline Year & Total Employment & \% Change Over Prior Year & Number of Establishments & \% Change Over Prior Year \\
\hline $\mathbf{2 0 0 5}$ & 87,667 & & 63,726 & $13.08 \%$ \\
$\mathbf{2 0 0 6}$ & 97,847 & $11.61 \%$ & 72,063 & $6.00 \%$ \\
$\mathbf{2 0 0 7}$ & 105,654 & $8.00 \%$ & 76,386 & $15.37 \%$ \\
$\mathbf{2 0 0 8}$ & 120,034 & $13.61 \%$ & 88,125 & $11.91 \%$ \\
$\mathbf{2 0 0 9}$ & 134,543 & $12.09 \%$ & 98,624 & \\
\hline
\end{tabular}

Panel B: D\&B Data: Los Angeles Companies With Sales Over \$100,000

\begin{tabular}{lcccc}
\hline Year & Total Employment & \% Change Over Prior Year & Number of Establishments & \% Change Over Prior Year \\
\hline $\mathbf{2 0 0 5}$ & $1,404,225$ & & 135,299 & $3.34 \%$ \\
$\mathbf{2 0 0 6}$ & $1,400,613$ & $-.26 \%$ & 139,812 & $3.11 \%$ \\
$\mathbf{2 0 0 7}$ & $1,429,657$ & $2.07 \%$ & 144,159 & $7.06 \%$ \\
$\mathbf{2 0 0 8}$ & $1,414,663$ & $-1.05 \%$ & 154,335 & $9.83 \%$ \\
$\mathbf{2 0 0 9}$ & $1,430,485$ & $1.12 \%$ & 169,501 & \\
\hline
\end{tabular}

Panel C: D\&B Data: All Other California Companies (in MSAs) With Sales Under \$100,000

\begin{tabular}{ccccc}
\hline Year & Total Employment & \% Change Over Prior Year & Number of Establishments & \% Change Over Prior Year \\
\hline $\mathbf{2 0 0 5}$ & 432,775 & & 323,122 & $10.46 \%$ \\
$\mathbf{2 0 0 6}$ & 473,863 & $9.49 \%$ & 356,916 & $4.43 \%$ \\
$\mathbf{2 0 0 7}$ & 505,727 & $6.72 \%$ & 372,742 & $12.20 \%$ \\
$\mathbf{2 0 0 8}$ & 561,236 & $10.98 \%$ & 418,229 & $13.72 \%$ \\
$\mathbf{2 0 0 9}$ & 632,072 & $12.62 \%$ & 475,594 & \\
\hline
\end{tabular}

Panel D: LATAX Data: Companies With Gross Receipts Under \$100,000

\begin{tabular}{ccccccc}
\hline Year & $\begin{array}{c}\text { Gross } \\
\text { Receipts }\end{array}$ & $\begin{array}{c}\text { \% Change Over } \\
\text { Prior Year }\end{array}$ & Tax Paid $^{17}$ & $\begin{array}{c}\text { \% Change Over } \\
\text { Prior Year }\end{array}$ & $\begin{array}{c}\text { Number of } \\
\text { Companies Filing }\end{array}$ & $\begin{array}{c}\text { \% Change Over } \\
\text { Prior Year }\end{array}$ \\
\hline $\mathbf{2 0 0 5}$ & $\$ 6,434,533,390$ & & $\$ 26,765,944$ & & 311,255 & \\
$\mathbf{2 0 0 6}$ & $\$ 6,680,098,710$ & $3.82 \%$ & $\$ 25,486,724$ & $-4.78 \%$ & 330,671 & $6.23 \%$ \\
$\mathbf{2 0 0 7}$ & $\$ 6,979,040,365$ & $4.48 \%$ & $\$ 16,023,454$ & $-37.13 \%$ & 336,688 & $1.82 \%$ \\
$\mathbf{2 0 0 8}$ & $\$ 6,959,625,453$ & $-.28 \%$ & $\$ 11,130,533$ & $-30.54 \%$ & 326,750 & $-2.95 \%$ \\
$\mathbf{2 0 0 9}$ & $\$ 6,990,375,702$ & $.44 \%$ & $\$ 9,744,993$ & $-12.45 \%$ & 317,099 & $-2.95 \%$ \\
\hline
\end{tabular}

Panel E: LATAX Data: Companies With Gross Receipts Over \$100,000

\begin{tabular}{lcccccc}
\hline Year & Gross Receipts & $\begin{array}{c}\text { \% Change Over } \\
\text { Prior Year }\end{array}$ & Tax Paid & $\begin{array}{c}\text { \% Change Over } \\
\text { Prior Year }\end{array}$ & $\begin{array}{c}\text { Number of } \\
\text { Companies Filing }\end{array}$ & $\begin{array}{c}\text { \% Change Over } \\
\text { Prior Year }\end{array}$ \\
\hline $\mathbf{2 0 0 5}$ & $\$ 162,569,631,851$ & & $\$ 372,618,303$ & & 121,643 & \\
$\mathbf{2 0 0 6}$ & $\$ 175,727,718,188$ & $8.09 \%$ & $\$ 395,518,584$ & $6.15 \%$ & 130,481 & $7.27 \%$ \\
$\mathbf{2 0 0 7}$ & $\$ 194,430,753,689$ & $10.64 \%$ & $\$ 411,071,954$ & $3.93 \%$ & 137,181 & $5.13 \%$ \\
$\mathbf{2 0 0 8}$ & $\$ 206,561,747,814$ & $6.24 \%$ & $\$ 417,585,328$ & $1.58 \%$ & 141,181 & $2.92 \%$ \\
$\mathbf{2 0 0 9}$ & $\$ 212,417,857,838$ & $2.84 \%$ & $\$ 396,325,299$ & $5.09 \%$ & 143,529 & $1.66 \%$ \\
\hline
\end{tabular}

If we use instead, as a control group, other California firms not based in LA but based in other MSAs and with sales of under $\$ 100 \mathrm{k}$, we see the following results (Panel $\mathrm{C}$ of Table 5). These firms experienced 9.49\% and $6.72 \%$ growths in

\footnotetext{
${ }^{16}$ Note that a number of observations were lost because of restricting the sample to only those companies which reported sales data. These firms may have had some reported sales outside of Los Angeles. In that case, their Los Angeles sales are clearly under $\$ 500 \mathrm{k}$, qualifying them for the exemption.

${ }^{17}$ Tax paid does not include interest and penalties.

${ }^{18}$ Tax paid does not include interest and penalties.

${ }^{19}$ Note that a number of observations were lost because of restricting the sample to only those companies which reported sales data.
} 
employment from 2005-2006 and 2006-2007, respectively. Thus there was a 2.77\% decline, after controlling for trend, after 2006. Comparing them to the LA firms with sales of under $\$ 100 \mathrm{k}$, we see the latter experienced a relative decline of .84\% after the exemption. Averaging the above two comparisons, the small business exemption was not associated with any detectible job retention/creation. When we use the number of establishments, instead of employment, we find more encouraging results, with a net growth of $5.76 \%$ (comparing small firm growth to larger firm growth, and both groups controlling for pre law change trends). This difference in differences is significant at .001 (using a $Z$ test of differences in population proportions).

Aggregate LATAX data is shown in Panels D and E of Table 6. To evaluate the sales and number of firm growth for LA based firms subject to the new business exemption, we compare such firms' growth to control groups. To control for trends we compare changes in changes to the affected LA firms versus changes in changes to control group. ${ }^{20}$ The number of firms shows no measureable growth. Prior to the exemption (from 2005-2006), the number of LA firms with sales under $\$ 100 \mathrm{k}$ experienced a $6.23 \%$ growth. After the exemption, there was a $1.82 \%$ growth. Thus, the change, after controlling for the previous year's trend, was a $4.41 \%$ decrease in the number of firms. Prior to the exemption (from 2005-2006), the number of LA firms with sales over \$100k increased 7.27\%. After the exemption, there was a 5.13\% growth. Thus, the change, after controlling for the previous year's trend, was a $2.14 \%$ decrease. Thus, comparing the two groups of LA firms, the number of firms with sales under $\$ 100 \mathrm{k}$ experienced a $2.27 \%$ decrease (or $4.41 \%$ minus $2.14 \%)^{21}$

Averaging the LATAX and NETS result, we get a $2.88 \%$ growth rate in number of firms in the tax cut group. Estimating the elasticity associated with this is not straightforward. If we assume that any particular firm never has more than $\$ 100,000$ in gross receipts, this amounts to a $100 \%$ tax cut, in which case the elasticity is -.0288 . However, it is more likely that an average firm would eventually grow such that they would no longer be subject to the exemption, in which case the tax reduction is less than $100 \%$. Accordingly, the elasticity estimate of -.0288 would certainly increase. On the other hand, recall that the 2001 changes, which affected a much broader set of firms, resulted in a direct labor elasticity (with respect to each percent change in tax) of -.586 and -.207 for number of establishments. Averaging between the two tax cuts we get an elasticity of around -.25 , which is roughly consistent with the literature summary for intra-urban tax studies reported in Bartik (1991).

Econometric (DID regression) results are show in Table 7. Model (1) uses employment from D\&B data, and the comparison group is Los Angeles establishments with gross receipts $>\$ 100 \mathrm{k}$. Model (2) uses employment from D\&B data, and the comparison group is all other California establishments with gross receipts $<\$ 100 \mathrm{k}$. Model (1) estimates that the tax reductions increased employment by $2.66 \%$ for the tax cut group, while Model (2) estimates a $.33 \%$ increase, both of which are significant at .001 . The average of $1.5 \%$ lies between the $0 \%$ employment growth and the $2.88 \%$ growth in the number of firms reported above using aggregate data.

Table 7. Effects of 2007 Los Angeles Business Tax Changes_-Difference in Differences (DID) Econometric Analysis

\begin{tabular}{|c|c|c|}
\hline & $\begin{array}{l}\text { Growth in Employment } \\
\text { (1) }\end{array}$ & $\begin{array}{c}\text { Growth in Employment } \\
\text { (2) }\end{array}$ \\
\hline Constant & $.09133 * * *(.00336)$ & $-.01851 * * *(.000305)$ \\
\hline Tax & $.02657 * * *(.00343)$ & $.00330 * * *(.000501)$ \\
\hline $\begin{array}{l}\text { Establishment } \\
\text { dummies }\end{array}$ & Yes & Yes \\
\hline Year dummies & Yes & Yes \\
\hline $\begin{array}{l}\text { Number of } \\
\text { establishments }\end{array}$ & 471,114 & $4,756,839$ \\
\hline Model $F$ Statistic & $116.42 * * *$ & $11.45 * * *$ \\
\hline
\end{tabular}

$* / * * / * * *$ denote significance at the $5 \%, 1 \%$, and $0.1 \%$ levels, respectively. Robust standard errors in parentheses. Time period is 2005 through 2009. Model (1) uses D\&B data, and the comparison group is Los Angeles establishments with gross receipts $>\$ 100 \mathrm{k}$. Model (2) uses D\&B data, and the comparison group is all other California establishments with

\footnotetext{
${ }^{20}$ The Table also shows gross receipts and taxes paid for each group. These are for information only, since both are expected to drop for the smaller firms due to the tax break (which is what we observe).

${ }^{21}$ Regarding the weak findings using the D\&B data, the Great Recession may have had a disproportionate effect on small firms. It is also important to realize that during this same time, overall City tax rates were falling, so any comparisons to other LA based firms may have been misleading. Tax rates were reduced by $3.1 \%$ in 2006 , and $4 \%$ in 2007. Also, the firms affected by the 2007 exemption were very small, primarily composed of sole proprietorships which historically have a high birth and death rate, relative to other firms. Further, sole proprietors' location choice decisions are often primarily driven by proximity to where they live.
} 
gross receipts $<\$ 100 \mathrm{k}$.

\section{Conclusion}

This paper first documents the overall magnitudes of city business taxes nationally, and finds that such taxes are a relatively significant cost to business. Additionally, the study uses a unique dataset to find that municipal tax cuts generally resulted in growth in both the number of jobs and establishments in a major city. Although preliminary and of course only suggestive due to the case study nature here, the average elasticity of around -.25 for the two tax cuts is roughly consistent with the literature summary for intra-urban tax studies reported in Bartik (1992).

When we also consider that prior research has found that economic activity is also responsive to municipal property taxes, the results suggest that cities may be able to alter their tax structures to attract economic activity.

\section{References}

Bartik, T. J. (1992). The effects of state and local taxes on economic development: a review of recent research. Economic Development Quarterly, (6), 102-111. https://doi.org/10.1177/089124249200600110

Duranton, G., Gobillon, L., \& Overman, H. (2011). 2011. Assessing the effects of local taxation using microgeographic data. The Economic Journal, 121(September), 1017-1046. https://doi.org/10.1111/j.1468-0297.2011.02439.x

Dye, R., McGuire, T., \& Merriman, D. (2001). The impact of property taxes and property tax classifications on business activity in the Chicago metropolitan area. Journal of Regional Science, 41, 757-778. https://doi.org/10.1111/0022-4146.00242

Ham, J., Swenson, C., Imrohoroglu, I., \& Song, H. (2011). Government programs can improve local labor markets: evidence from state enterprise zones and federal empowerment zones. Journal of Public Economics (August). https://doi.org/10.1016/j.jpubeco.2010.11.027

Luce, T. (1994). Local taxes, public services, and the intra-metropolitan location of firms and households. Public Finance Quarterly, 22, 139-167. https://doi.org/10.1177/109114219402200201

Mark, S., McGuire, T., \& Papke, L. (2000). The influence of taxes on employment and economic growth: evidence from the Washington D.C. metropolitan area. National Tax Journal, 53, 105-123. https://doi.org/10.17310/ntj.2000.1.06

Rathelot, R., \& Sillard, P. (2008). The importance of local corporate income taxes in business location decisions: Evidence from French micro data. Economic Journal, 118(March), 499-514. https://doi.org/10.1111/j.1468-0297.2007.02131.x

Wasmer, R., \& Anderson, J. (2001). Bidding for business: new evidence on the effect of locally offered economic development incentives in a metropolitan area. Economic Development Quarterly, 15(June), 132-148. https://doi.org/10.1177/089124240101500203

Wu, Y. (2010). Property tax exportation and its effect on local business establishments: the case of Massachsussetts municipalities. Economic Development Quarterly, 24(1), 3-12. https://doi.org/10.1177/0891242409341579

\section{Copyrights}

Copyright for this article is retained by the author(s), with first publication rights granted to the journal.

This is an open-access article distributed under the terms and conditions of the Creative Commons Attribution license which permits unrestricted use, distribution, and reproduction in any medium, provided the original work is properly cited. 